\title{
Significant Earthquakes on the Enriquillo Fault System, Hispaniola, 1500-2010: Implications for Seismic Hazard
}

\author{
by William H. Bakun, Claudia H. Flores, and Uri S. ten Brink
}

\begin{abstract}
Historical records indicate frequent seismic activity along the north-east Caribbean plate boundary over the past 500 years, particularly on the island of Hispaniola. We use accounts of historical earthquakes to assign intensities and the intensity assignments for the 2010 Haiti earthquakes to derive an intensity attenuation relation for Hispaniola. The intensity assignments and the attenuation relation are used in a grid search to find source locations and magnitudes that best fit the intensity assignments.

Here we describe a sequence of devastating earthquakes on the Enriquillo fault system in the eighteenth century. An intensity magnitude $M_{\mathrm{I}} 6.6$ earthquake in 1701 occurred near the location of the 2010 Haiti earthquake, and the accounts of the shaking in the 1701 earthquake are similar to those of the 2010 earthquake. A series of large earthquakes migrating from east to west started with the 18 October 1751 $M_{\text {I }}$ 7.4-7.5 earthquake, probably located near the eastern end of the fault in the Dominican Republic, followed by the 21 November $1751 M_{\mathrm{I}} 6.6$ earthquake near Port-au-Prince, Haiti, and the 3 June $1770 M_{\mathrm{I}} 7.5$ earthquake west of the 2010 earthquake rupture. The 2010 Haiti earthquake may mark the beginning of a new cycle of large earthquakes on the Enriquillo fault system after 240 years of seismic quiescence. The entire Enriquillo fault system appears to be seismically active; Haiti and the Dominican Republic should prepare for future devastating earthquakes.
\end{abstract}

Online Material: Table listing small earthquakes, and figures of intensity assignments and intensity magnitude estimates.

\section{Introduction}

The 12 January 2010 M 7.0 Haiti earthquake devastated Port-au-Prince, largely because the city was not prepared. Southern Haiti had been seismically quiet in living memory, the devastating earthquakes of the distant past long forgotten by many Haitians. Here we consider the historical earthquake activity, and its implications for seismic hazard mitigation efforts.

The five centuries of seismic history of the island of Hispaniola is arguably the longest in the western hemisphere. Hispaniola was rapidly colonized by Spain after its discovery by Columbus in 1492, but Hispaniola's Spanish population started declining following the Spanish discovery of gold in Mexico in 1519 and in Peru in 1532. The western third of Hispaniola (present-day Haiti), after being deserted by the Spaniards in 1606, was populated largely by French, Dutch, and English pirates in the seventeenth century and became a French possession in 1697. That colony, and later independent Haiti (1791), was relatively prosperous until the beginning of the twentieth century (Moreau de Saint Mery, 1798; Hazard, 1873; Garcia, 1900).
There are ample Spanish, French, and British accounts describing the social and physical conditions of Hispaniola in the past 500 years (Charlevoix, 1730; Oldmixon, 1741; Moreau de Saint Mery, 1796, 1798; Southey, 1827; de Velasco, 1894). Contemporary sixteenth-, seventeenth-, and eighteenth-century maps of Hispaniola (Boston Public Library, see Data and Resources) show towns located within a few tens of kilometers of the Enriquillo fault: 4 towns in 1579 ; 5 towns in 1628,1630 , and 1633; and 14 towns in 1725. (The Enriquillo fault in southern Hispaniola and the Plaintain Garden fault in eastern Jamaica form a continuous geomorphic lineament through the Caribbean Sea, sometimes referred to as the Enriquillo Plaintain Garden fault. We consider here only earthquakes in Hispaniola, i.e., on or near the Enriquillo fault.) Nine hurricanes were reported in Hispaniola between 1494 and 1548 (Moreau de Jonnes, 1822; Poey, 1855), but the first reported severe earthquake took place in northern Dominican Republic on 2 December 1562 (Moreau de Jonnes, 1822; Poey, 1857; deUtrera, 1927). We note that 
there is some controversy about the year: 1562 or 1564 (see ten Brink et al., 2012).

The first reported earthquake in southwestern Hispaniola occurred on 9 November 1701, followed by significant earthquakes on 18 October 1751, 21 November 1751, and on 3 June 1770 (Table 1). In contrast to the seismically active eighteenth century, there is no evidence of significant damaging earthquake activity near the Enriquillo fault in Haiti in the 200 years before 1701, even though there were regular official reports throughout that period describing natural events that affected the economy of all of Hispaniola. Although small earthquakes have been felt in recent years, there is no evidence of significant earthquake activity on the Enriquillo fault system in the 240 years from 1770 to 2010, except for an $M_{\mathrm{I}} 6.3$ earthquake on 18 April 1860, which probably occurred offshore on a secondary structure.

The contrast of intense seismic activity along the Enriquillo fault system in the eighteenth century, culminating with the 3 June 1770 intensity magnitude $M_{\mathrm{I}} 7.5$ event, and the apparent centuries-long periods of significant earthquake quiescence, before and after, is not unique. Fifty-six years of significant earthquake activity (1850-1906) in northern California, culminating in the 1906 moment magnitude M 7.8 earthquake on the San Andreas fault, has been followed by more than 100 years of relative seismic quiescence (Bakun, 1999). Analyses of the historical seismicity and other data by the Working Group on California Earthquake Probabilities (WGCEP) imply a significant likelihood of future damaging earthquake activity in the San Francisco Bay region (WGCEP, 2003). The details of significant seismic activity along the Enriquillo fault system over the past 500 years and the implications for future significant earthquake activity are the subjects of this study. While the eighteenth-century earthquakes have been identified by others (e.g., Scherer, 1912; McCann, 2006; Ali et al., 2008), we use rigorous statistical and grid search techniques to locate these earthquakes and estimate their magnitudes.

Table 1

Significant Enriquillo Fault System Earthquakes

\begin{tabular}{lccc}
\hline \multicolumn{1}{c}{ Date } & Lat $\left({ }^{\circ} \mathrm{N}\right)$ & Long $\left({ }^{\circ} \mathrm{W}\right)$ & \multicolumn{1}{c}{$M_{\mathrm{I}}{ }^{*}$} \\
\hline 9 November 1701 & $18.42^{\ddagger}$ & $72.65^{\ddagger}$ & $6.6 \pm 0.3$ \\
18 October 1751 & $18.36^{\ddagger}$ & $70.84^{\ddagger}$ & $7.4-7.5 \pm 0.2^{\S}$ \\
21 November 1751 & $18.54^{\ddagger}$ & $72.32^{\ddagger}$ & $6.6 \pm 0.2$ \\
3 June 1770 & $18.50^{\ddagger}$ & $72.86^{\ddagger}$ & $7.5 \pm 0.2$ \\
8 April 1860 & $18.55^{\dagger}$ & $73.17^{\ddagger}$ & $6.3 \pm 0.2$ \\
12 January 2010 & 18.45 & 72.54 & $\mathbf{M} 7.0$ \\
\hline
\end{tabular}

$* M_{\mathrm{I}}$ is our best estimate of $\mathbf{M} . \pm$ is the $1 \sigma$ range.

${ }^{\dagger}$ Probably located offshore north of the Enriquillo fault system. *Preferred location obtained using weighted preferred intensity assignments. Weights are proportional to the number of assignments for that site.

${ }^{\S} M_{\mathrm{I}} 8$ if located on the Los Muertos trough.

\section{Tectonic Setting}

The island of Hispaniola is part of the Antilles island arc, which wraps around the Caribbean plate from Cuba to the Virgin Islands to Trinidad and to Curacao (Fig. 1). The arc developed during the early Cretaceous, but the segment from Cuba to the Virgin Islands has not been active magmatically since early Eocene-Oligocene time (Mann et al., 1991). The cessation of magmatic activity was likely the result of the collision of the Bahamas carbonate platform, situated on the North America (NOAM) plate, with the Antilles arc in Cuba, which forced a change in interplate convergence direction from northeast-southwest to eastnortheast-west-southwest (Pindell and Barrett, 1990). Presently, the eastern tail of the buoyant Bahamas platform collides obliquely with the arc along a $220-\mathrm{km}$-long section in northern Hispaniola between $68.5^{\circ} \mathrm{W}$ and $70.5^{\circ} \mathrm{W}$ (Dolan and Wald, 1998; Dolan et al., 1998). The collision is partly being absorbed by compressional deformation and uplift in central Hispaniola (e.g., Heubeck and Mann, 1991; Pubellier et al., 2000) and partly by left-lateral motion on the Septentrional and Enriquillo-Plantain Garden strike-slip fault systems (Fig. 1). The uplift, and perhaps the formation of the Enriquillo fault, are thought to have started in mid-to-late Miocene (McLaughlin and Sen Gupta, 1991; Mann et al., 1995, Pubellier et al., 2000). The Septentrional fault may be older (Oligocene age), having accommodated intra-arc separation and eastward movement of Hispaniola away from Cuba (Dolan et al., 1998). The subduction and collision of the NOAM plate appears to be presently driving the internal deformation of the arc, probably including the Enriquillo fault (Manaker et al., 2008).

\section{The 12 January 2010 Earthquake}

The 12 January 2010 M 7.0 earthquake had a complicated source (Calais et al., 2010; Hayes et al., 2010). Although kinematic models of the deformation include some deep left-lateral slip, surface faulting on the nearby Enriquillo fault was not observed (Prentice et al., 2010) and significant slip on multiple nearby blind thrusts apparently is required (Hayes et al., 2010). That is, slip in the 2010 earthquake was not confined to the Enriquillo fault but involved nearby associated strike-slip, thrust, and normal faults that together accommodate relative motion between the NOAM and Caribbean plates near the Enriquillo fault. The 2010 earthquake thus occurred on the Enriquillo fault system, not on the Enriquillo fault.

The westward extent of aftershock locations and the geodetic modeling (Calais et al., 2010; Hayes et al., 2010) suggest that the 2010 rupture extended west about $20 \mathrm{~km}$ from the mainshock epicenter. A local seismic network did not exist in Haiti when the 2010 mainshock occurred, so the mainshock hypocenter is poorly constrained. Temporary local networks installed after the earthquake have provided some details of the late aftershocks. The majority 


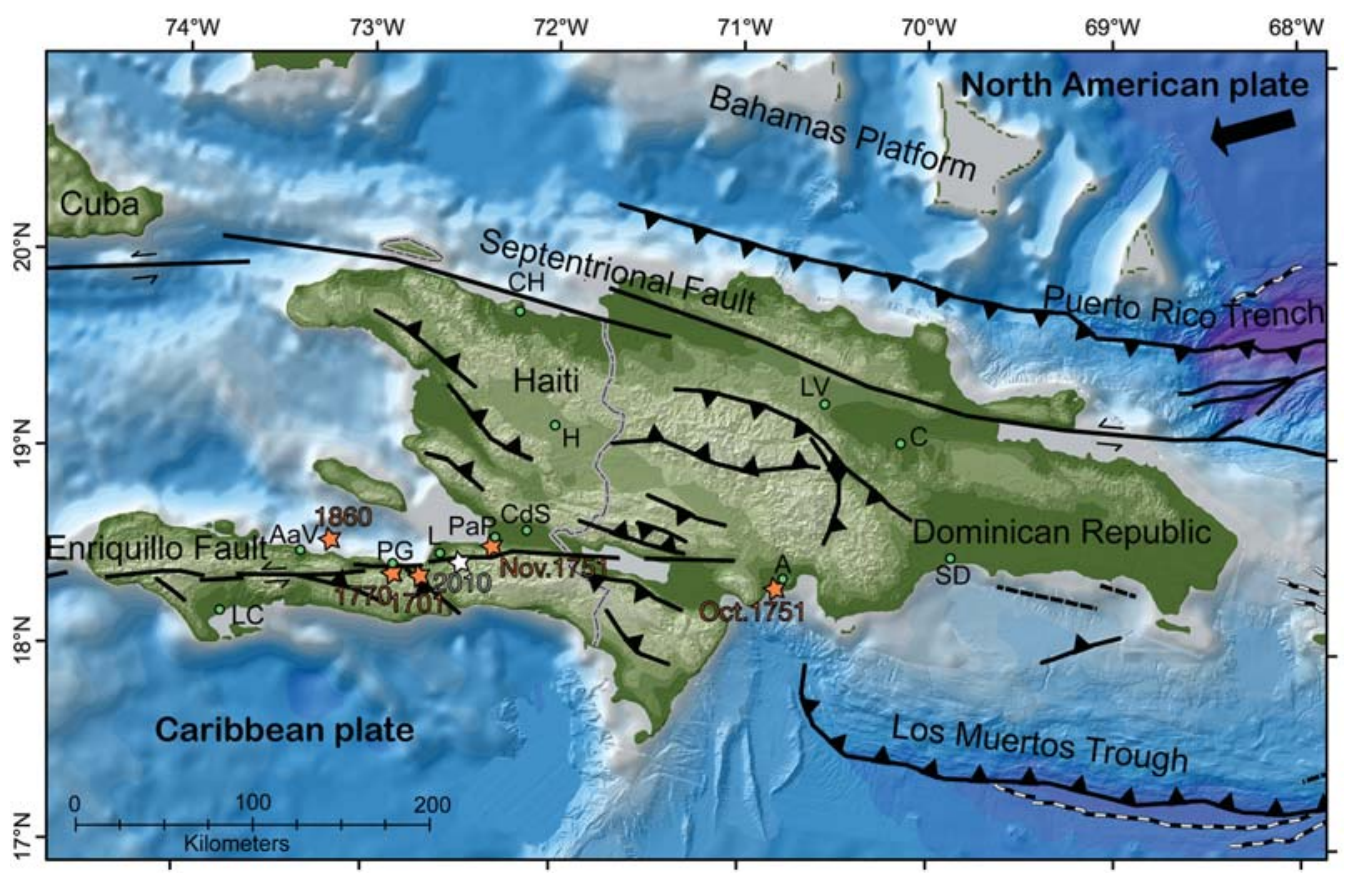

Figure 1. Map of Hispaniola (Haiti and the Dominican Republic). Fault traces are shown as black lines (barbed, thrust; solid, strike-slip; black and white, normal). The arrow shows the direction of the North American plate motion relative to the Caribbean plate. The intensity centers of historical events on or near the Enriquillo fault are shown as orange stars. The epicenter of the 2010 mainshock is shown as a white star. The zone of 2010 aftershocks, and the presumed rupture of the 2010 mainshock, is located along the Enriquillo fault from the white star to the 1701 earthquake orange star. The small green circles are the locations of towns mentioned in the text: A, Old Azua; AaV, Anse a Veau; C, Cotui; CdS, Cul-de-Sac; CH, Cap Haitien; H, Hinche; L, Leogane; LC, Les Cayes; LV, La Vega; PaP, Port-au-Prince; PG, Petit Goave; SD, Santo Domingo.

of late aftershock epicenters are clustered about $20 \mathrm{~km}$ west of the proposed mainshock epicenter, consistent with a mainshock rupture extending from the epicenter about $20 \mathrm{~km}$ toward the west and focal depths extending to about $20 \mathrm{~km}$ (Altidor et al., 2010).

\section{Intensity data}

We have assembled a large catalog of damage descriptions (Flores et al., 2011), which is based not only on older catalogs but also on letters, books, and other primary sources. We used the descriptions to assign intensities for earthquakes felt in Hispaniola over the past 500 years. The modified Mercalli intensity (MMI) scale (Wood and Neumann, 1931), like every intensity scale, includes recipes for assigning intensity based on damage to buildings made of known brittle material (e.g., adobe or un-reinforced masonry) or constructed using designs particularly vulnerable to shaking from earthquakes. Such buildings often sustain significant damage or complete failure for levels of shaking that do not damage nearby buildings constructed according to earthquake-resistant standards.

Building materials and construction practices in Hispaniola have likely been poor in both the near and the distant past. The 12 January 2010 M 7.0 earthquake devastated Port-au-Prince because many structures were vulnerable to even modest levels of earthquake shaking, but wellconstructed buildings in the city generally were not damaged
(Eberhard et al., 2010). We ranked the levels of destruction described in the accounts (Flores et al., 2011) and tied these levels to the MMI scale, according to the association of damage with intensity shown in Table 2.

The USGS/Earthquake Engineering Research Institute (EERI) Advance Reconnaissance Team (Eberhard et al., 2010) did not see much damage of the one-story, cementblock-wall structures that comprise most of the housing in

Table 2

Intensity Criteria

\begin{tabular}{cc}
\hline MMI* & Damage \\
\hline IX & $\begin{array}{c}\text { Total Destruction. } \\
\text { VIII }\end{array} \begin{array}{c}\text { Most structures destroyed. Only a few buildings } \\
\text { remain standing. }\end{array}$ \\
VII & $\begin{array}{c}\text { Damage to several structures. Most of the building } \\
\text { stock remains standing. }\end{array}$ \\
VI & $\begin{array}{c}\text { Some damage reported for a few significant } \\
\text { structures. Damage to the cathedral was often } \\
\text { reported to secure rebuilding funds from Spain. }\end{array}$ \\
V $\quad \begin{array}{c}\text { No damage reported. Intensity V, as described } \\
\text { in Richter (1958). }\end{array}$ \\
IV $\quad \begin{array}{c}\text { No damage reported. Intensity IV, as described } \\
\text { in Richter (1958). }\end{array}$ \\
III $\quad \begin{array}{c}\text { No damage reported. Intensity III, as described } \\
\text { in Richter (1958). }\end{array}$
\end{tabular}

*Half intensity levels are used (e.g.; VI $1 / 2$, for damage reports sufficient or VI but not clearly VII, major damage reported for a few structures). 
Port-au-Prince. In contrast, they found numerous examples of severe damage and collapse to the residences, hotels, and public buildings with heavy concrete slab floors and roofs. That is, many, but not most, structures in Port-au-Prince were damaged. This account can be compared with the damage criteria that we used for assigning intensity for historical earthquakes (Table 2). Most structures in Port-au-Prince were not destroyed, so our assigned intensity would be less than VIII. Damage was reported for more than a few significant structures, so our assigned intensity would be greater than VII. An MMI of 7.4 for Port-au-Prince was assigned for the 12 January 2010 M 7.0 earthquake using the Did You Feel It internet survey (Earthquake Hazards Program, 2010a). The Port-au-Prince MMI assignment is consistent with the damage intensity association criteria (Table 2) used for assigning intensities to historical earthquakes.

Assigning intensities based on damage descriptions is the only subjective part of this study. We attempt to assess the uncertainty in our results introduced by the necessarily subjective assignment of intensities by analyzing two independent sets of intensity assignments, one by $\mathrm{C}$. $\mathrm{H}$. Flores (CHF) and the second by W. H. Bakun (WHB), for each historical earthquake (Flores et al., 2011). Despite the sometimes very different intensity assignments, the resulting intensity center locations and intensity magnitudes for the significant historical earthquakes that we associate with the Enriquillo fault system are surprisingly consistent (E) see Figs. S6-S10, available as an electronic supplement to this paper).

We combined the CHF and WHB assignment sets to obtain a preferred intensity assignment set. Note that WHB declined to assign intensity values for some sites with lessdescriptive reports, labeled WHB (-) by Flores et al. (2011). The preferred assignment is an average of the CHF and WHB assignments. Sites with two assignments are double weighted in the analyses of the preferred intensity assignment sets. We anticipate that additional historical sources will expand our archive of accounts (Flores et al., 2011), perhaps with accounts critical to our understanding of the historical seismicity on the Enriquillo fault system.

We can estimate an approximate location and magnitude for an historical earthquake from intensity assignments, but not a focal mechanism. Moreover, the locations from intensity data are not accurate enough to discriminate the specific causative fault(s) for earthquakes located near the Enriquillo fault system. That is, a location on or near the Enriquillo fault system encompasses a range of possible, unknowable fault(s) and focal mechanism(s). Perhaps every historical Enriquillo fault system event is complicated, with slip on strike-slip, normal, and thrust faults of unknown location, orientation, and focal mechanism.

\section{Intensity Attenuation Model}

We used 96 MMI $>2.0$ assignments (Earthquake Hazards Program, 2010a) for the three largest 2010 Haiti earthquakes (65 for the 12 January 2010 M 7.0 mainshock, 20 for the 20 January 2010 M 5.9 aftershock, and 11 for the 22 February 2010 M 4.7 aftershock) to estimate the intensity attenuation relation for Hispaniola. A regression on the 96 data points using the Microsoft EXCEL data analysis regression tool (Middleton, 1995) yielded the relation

$$
\begin{aligned}
\text { MMI }= & -(1.69 \pm 0.81)+(1.70 \pm 0.19) * \mathbf{M} \\
& -(0.00165 \pm 0.00054) * \Delta_{h} \\
& -(2.13 \pm 0.34) * \log _{10}\left(\Delta_{h}\right),
\end{aligned}
$$

where $\mathbf{M}$ is moment magnitude and $\Delta_{h}$ is the hypocentral distance in kilometers of the MMI site from a point source at $h=10 \mathrm{~km}$ depth. The MMI residuals do not depend on the variables $\mathbf{M}, \Delta_{h}$, and $\log _{10}\left(\Delta_{h}\right)$. The intensity attenuation relation in equation (1) is similar to that obtained for southern California (Bakun, 2006; Fig. 2).

\section{Method of Analysis}

We use equation (1) to estimate $M$ from individual intensity observations for a trial epicenter (Bakun and Wentworth, 1997). That is,

$$
M_{\mathrm{I}}=\operatorname{mean}\left(M_{\mathrm{i}}\right) \text {, }
$$

where

$$
M_{\mathrm{i}}=\left[\mathrm{MMI}_{\mathrm{i}}+1.69+0.00165 \Delta_{\mathrm{h}, \mathrm{i}}+2.13 \log \left(\Delta_{\mathrm{h}, \mathrm{i}}\right)\right] / 1.7,
$$

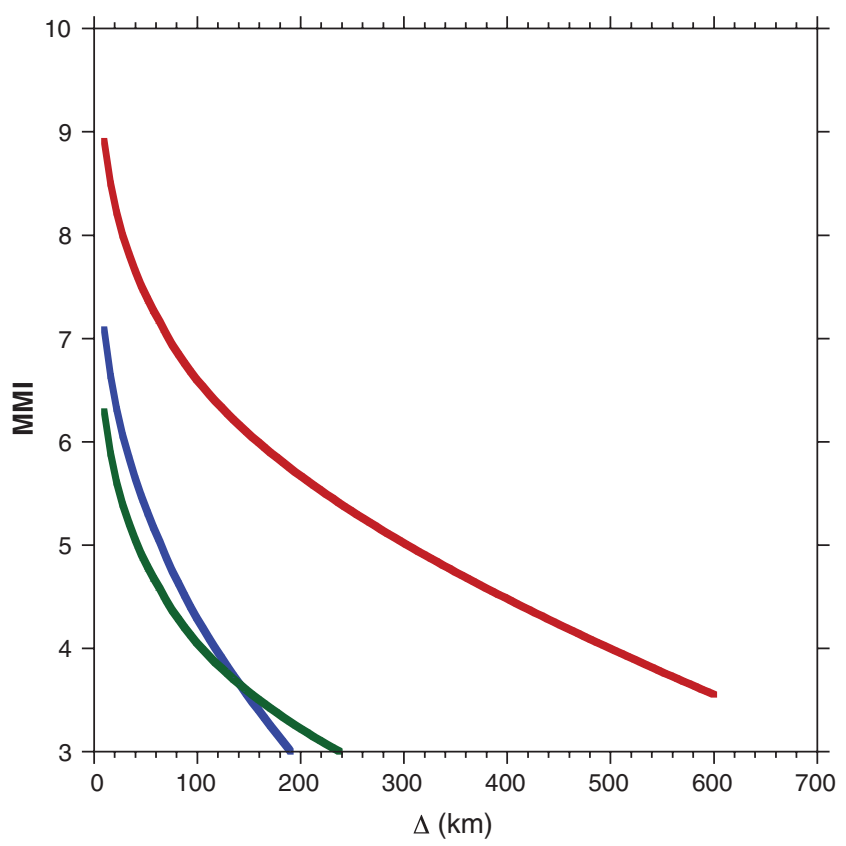

Figure 2. MMI attenuation. MMI for an $\mathbf{M} 6.0$ source at $10-\mathrm{km}$ depth in Haiti (equation 1) is shown in green relative to the same magnitude earthquake in California (Bakun, 2006) and in the stable continental region of eastern North America (Bakun and Hopper, 2004), shown in blue and red, respectively. 
$\mathrm{MMI}_{\mathrm{i}}$ and $\Delta_{\mathrm{h}, \mathrm{i}}$ are the intensity value and the hypocentral distance, respectively, at site $i$.

We find the misfit for each trial epicenter from

$$
\operatorname{rms}\left[M_{\mathrm{I}}\right]=\left[\operatorname{rms}\left(M_{\mathrm{I}}-M_{\mathrm{i}}\right)-\operatorname{rms}_{0}\left(M_{\mathrm{I}}-M_{\mathrm{i}}\right)\right],
$$

where $\quad \operatorname{rms}\left(M_{\mathrm{I}}-M_{\mathrm{i}}\right)=\left\{\Sigma_{\mathrm{i}}\left[\mathrm{W}_{\mathrm{i}}\left(M_{\mathrm{I}}-M_{\mathrm{i}}\right)\right]^{2} / \Sigma_{\mathrm{i}} \mathrm{W}_{\mathrm{i}}^{2}\right\}^{1 / 2}$, $\mathrm{rms}_{0}\left(M_{\mathrm{I}}-M_{\mathrm{i}}\right)$ is the minimum $\operatorname{rms}\left(M_{\mathrm{I}}-M_{\mathrm{i}}\right)$ over the grid of trial epicenters, and $\mathrm{W}_{\mathrm{i}}$ is the distance-weighting function (Bakun and Wentworth, 1997)

$$
\mathrm{W}_{\mathrm{i}}= \begin{cases}0.1+\cos \left[\left(\Delta_{\mathrm{i}} / 150\right)(\pi / 2)\right] & \text { for } \Delta_{\mathrm{i}}<150 \mathrm{~km} \\ 0.1 & \text { for } \Delta_{\mathrm{i}}>150 \mathrm{~km}\end{cases}
$$

The intensity center is the trial source location for which $\operatorname{rms}\left[M_{\mathrm{I}}\right]$ is minimum (Bakun, 1999) and corresponds more to the moment centroid than to the epicenter.

The $\operatorname{rms}\left[M_{\mathrm{I}}\right]$ contours bound the intensity center region and are associated with confidence levels that the intensity center is located within the contour (Bakun and Wentworth, 1997). The $M_{\mathrm{I}}$ at trial locations are the best estimates of moment magnitude $\mathbf{M}$ for these source locations. Uncertainties in $\mathbf{M}$ appropriate for the number of MMI assignments are also estimated (Bakun and Wentworth, 1999).

\section{Verification Tests}

The three 2010 calibration events used to obtain equation (1) were located on the Enriquillo fault system. Location estimates using intensity data are controlled primarily by the geographical distribution of the intensity sites relative to the source; the intensity attenuation relation is generally not important for estimating the source location. The intensity attenuation relation is critical in the estimation of magnitude. Analyses of the intensity assignments for the three 2010 calibration events satifactorily reproduced the instrumental magnitudes (E) see Figs. S1-S3, available as an electronic supplement to this paper).

\section{The 28 October 1952 Earthquake}

Sykes and Ewing (1965) used 108 seismographs to estimate a location $\left(18.51^{\circ} \mathrm{N}, 73.52^{\circ} \mathrm{W}\right)$ and an $M_{\mathrm{s}}$ of 5.9. The epicenter is near the Enriquillo fault, so the 1952 event provides an independent test of equation (1). Shaking was strongest at Anse-a-Veau (Bettembourg et al., 1955). The descriptions of effects (Bettembourg et al., 1955) were used to assign intensity at 23 sites by CHF and at 12 sites by WHB. We combined the assignments, as described previously, and analyzed the resulting preferred set of intensity assignments (E) see Fig. S4, available as an electronic supplement to this paper). The intensity center is $19 \mathrm{~km}$ east of the epicenter and $M_{\mathrm{I}}$ is $6.0 \pm 0.2$.

\section{The 12 May 2005 Earthquake}

The epicenter of the 12 May $2005 m_{\mathrm{b}} 4.3$ earthquake was located near the Enriquillo fault system near Port-auPrince (Earthquake Hazards Program, 2010b). We use MMI values at six sites assigned using online Did You Feel It? responses (Earthquake Hazards Program, 2010a). The intensity center is located $20 \mathrm{~km}$ east of the epicenter (E) see Fig. S5, available as an electronic supplement to this paper). $\mathrm{M}_{\mathrm{I}}$ is $5.2 \pm 0.2$, greater than the instrumental $m_{\mathrm{b}} 4.3$.

There are two outstanding calibration verification questions: (1) is equation (1) applicable to events larger than the 2010 M 7.0 Haiti mainshock; (2) is equation (1) applicable to other source regions in Hispaniola, particularly for subduction earthquakes? Unfortunately, there are not many events in Hispaniola with known instrumental locations and magnitudes and with sufficient intensity assignments to test equation (1). A notable exception is the 4 August 1946 Puerto Rico Trench subduction earthquake.

\section{The 4 August 1946 Puerto Rico Trench Earthquake}

The 4 August 1946 earthquake, located at the Puerto Rico Trench near the north coast of Hispaniola, was a large subduction-zone event. The intensity assignments for the 1946 event (Lynch and Bodle, 1948; O'Loughlin and Lander, 2003) were analyzed using the techniques described previously. The intensity center is near the reported tsunami, about 100 kilometers west-northwest of the epicenter (Fig. 3), but within the rupture zone defined by Dolan and Wald (1998) for the 1946 earthquake. The instrumental magnitude

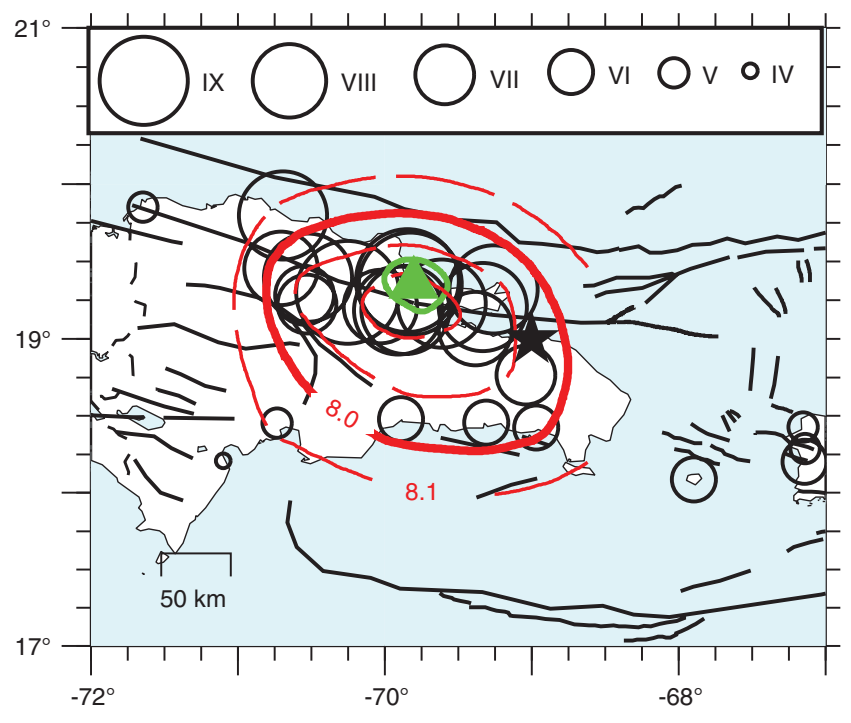

Figure 3. The 4 August 1946 Dominican Republic subduction earthquake on the Puerto Rico trench. Black circles are sites with MMI assignments with symbol size increasing with intensity. The black lines are active fault traces. The epicenter is a black star. The intensity center is a green filled triangle. Contours of $M_{\mathrm{I}}$ are dashed red lines. The rms $\left(M_{\mathrm{I}}\right)$ contour corresponding to the $67 \%$ confidence contours for location (Bakun and Wentworth, 1999) is a green line. 
estimates vary: $M_{\mathrm{s}} 8.1$ (Kelleher et al., 1973; Earthquake Hazards Program, 2010b); $M_{\mathrm{s}} 8.0$ (Abe, 1981); and $M_{\mathrm{s}} 7.8$ (Pacheco and Sykes, 1992; Russo and Villaseñor, 1995). Our $M_{\mathrm{I}}=7.8 \pm 0.2$ is consistent with these estimates, providing evidence that equation (1) can be used for large Hispaniola earthquakes and for subduction-zone sources.

\section{Verification Results}

The intensity center locations for the verification events are acceptably close to the instrumental epicenters, given the extended rupture length of the 1946 event and the $\sim 20-\mathrm{km}$ accuracy expected for epicenters based on teleseismic arrival times. The $M_{\mathrm{I}}$ for the four $\mathrm{M} \geq 6.0$ events are consistent with the instrumental estimates of magnitude. The $M_{\mathrm{I}} 5.2 \pm 0.2$ obtained for the 2005 event is greater than the instrumental $m_{\mathrm{b}} 4.3$, and the $M_{\mathrm{I}} 5.0 \pm 0.2$ obtained for the 22 February 2010 aftershock is greater than the instrumental $\mathbf{M} 4.7$. We conclude that $M_{\mathrm{I}}$ estimated using equation (1) and the intensity analysis methodology described previously are accurate estimates of $\mathbf{M}$ for $M_{\mathrm{I}} 6.0$ and larger events in Hispaniola; equation (1) can be used to provide unbiased estimates of location and $\mathbf{M}$ for crustal and subduction-zone earthquakes throughout Hispaniola.

\section{Significant Eighteenth-Century Enriquillo Fault System Earthquakes}

Four significant mainshocks, on 9 November 1701, 18 October 1751, 21 November 1751, and 3 June 1770,

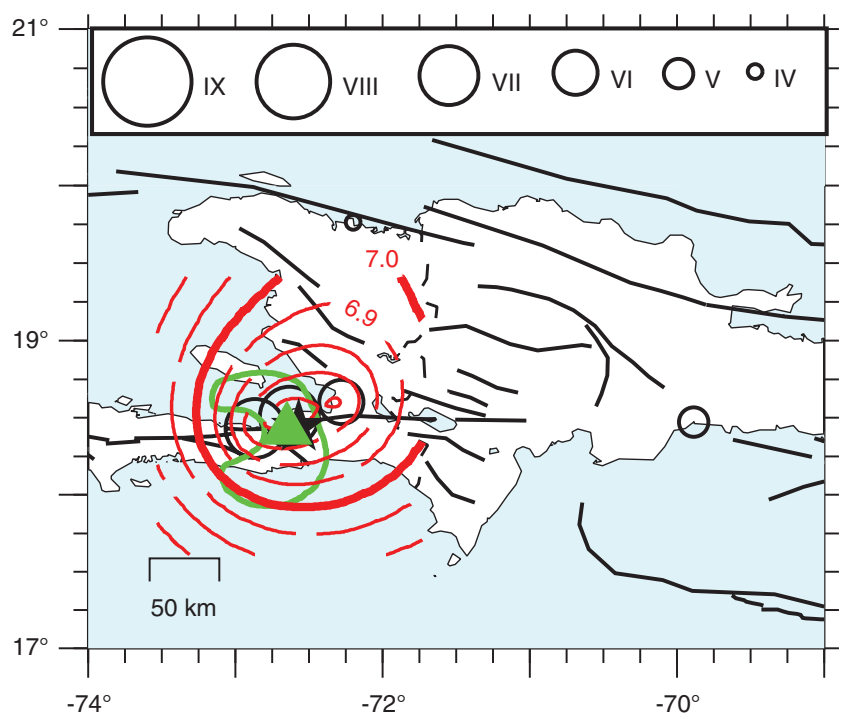

Figure 4. The 9 November 1701 earthquake with the preferred intensity assignments. The black circles are sites with MMI assignments with symbol size increasing with intensity. The black lines are active fault traces. The intensity center is a green filled triangle. Contours of $M_{\mathrm{I}}$ are dashed red lines. The rms $\left(M_{\mathrm{I}}\right)$ contour corresponding to the $67 \%$ confidence contours for location (Bakun and Wentworth, 1999) is a green line. The epicenter of the 12 January 2010 mainshock is shown as a black star. occurred in the 70 years from 1701 to 1770 (Table 1), with apparently vigorous aftershock sequences and possible foreshock activity. An $M_{\mathrm{I}} 6.3$ earthquake on 8 April 1860 occurred near the Enriquillo fault system, but probably offshore to the north.

\section{November 1701}

The first reported earthquake from the western part of Hispaniola was the 9 November 1701 earthquake, four years after the French takeover of Haiti (Fig. 4). The 1701 event caused great destruction in several villages from Cul-de-Sac to Petit Goave (Moreau de Saint Mery, 1798; Scherer, 1912; Taber, 1922). Maximum destruction was reported in Leogane. The road leading from Leogane to Petit Goave along the coast collapsed (Moreau de Saint Mery, 1798).

The accounts are sufficient to assign intensity at five sites (Table 3). The assignments by WHB and CHF are different at Petit Goave, Cap Haitien, and Santo Domingo. Cap Haitien and Santo Domingo are distant sites so that, with distance weighting given by equation (5), their effect on the location estimate is small. Petit Goave, however, is near the epicentral region. For intensity VI at Petit Goave, the intensity center (source A in Table 3 ) is $5 \mathrm{~km}$ from the 2010 mainshock epicenter (E) see Fig. S6a, available as an electronic supplement to this paper). For intensity VII at Petit Goave, the intensity center (source B in Table 3 ) is $20 \mathrm{~km}$ to the west, near the inferred west end of the 2010 rupture (E) see Fig. S6b, available as an electronic supplement to this paper). For the preferred intensity assignments, as defined in the Intensity Data section, the intensity center is $12 \mathrm{~km}$ west of the 2010 mainshock epicenter, $10 \mathrm{~km}$ west of Leogane, and close to the Leogane-to-Petit Goave collapsed road (Fig. 4). In any case, the intensity center for the 1701 event is located near the 2010 rupture zone and the Leogane-to-Petit Goave collapsed road. $M_{\mathrm{I}}$ is $6.6 \pm 0.3$.

The intensity assignments at Leogane, Cul-de-Sac, and Petit Goave are in good agreement with the expected intensity at these distances. In hindsight (Table 3), an intensity IV or V assignment at Cap Haitien and an intensity IV assignment at Santo Domingo would have been more consistent with the source solutions. This analysis suggests that the 1701 intensity assignments, and those of the other historical events, are uncertain by about one unit, particularly for the lower intensities where the available descriptions, e.g., "earthquake felt strongly" for Cap Haitien (Moreau de Saint Mery, 1798) and "quite strong" for Santo Domingo (Tippenhauer, 1893), contain information only marginally useful for assigning intensities.

\section{October 1751}

The city of Azua was destroyed and subsequently moved northward to its present location. Santo Domingo also suffered severe damage, as did the villages of Cotui, Hinche, and La Vega in the mountains north and northwest of Azua. The intensity centers and $M_{\mathrm{I}}$ for the CHF and WHB intensity 
Table 3

Intensity Assignments for 9 November 1701

\begin{tabular}{|c|c|c|c|c|c|c|}
\hline Site & Intensity (CHF) & Source A * & Intensity (WHB) & Source B ${ }^{\dagger}$ & Intensity (Preferred) & Preferred Source ${ }^{\ddagger}$ \\
\hline Cap Haitien & 3 & 4.3 & 4 & 4.9 & 3.5 & 4.6 \\
\hline Cul-de-Sac & 6 & 5.8 & 6 & 6.1 & 6.5 & 5.9 \\
\hline Leogane & 7 & 7 & 7 & 7.1 & 7 & 7 \\
\hline Petit Goave & 6 & 6 & 7 & 7 & 6.5 & 6.5 \\
\hline Santo Domingo & 4 & 3.5 & 5 & 4.1 & 4.5 & 3.8 \\
\hline
\end{tabular}

$* M_{\mathrm{I}} 6.4$ at $18.48^{\circ} \mathrm{N}, 72.60^{\circ} \mathrm{W}$ (solution using CHF intensity assignments).

${ }^{\dagger} M_{\mathrm{I}} 6.8$ at $18.37^{\circ} \mathrm{N}, 72.71^{\circ} \mathrm{W}$ (solution using WHB intensity assignments).

${ }^{\ddagger} M_{\mathrm{I}} 6.6$ at $18.42^{\circ} \mathrm{N}, 72.65^{\circ} \mathrm{W}$ (solution using preferred intensity assignments).

assignments depend critically on the intensity assigned for Santo Domingo. With an intensity VIII, the intensity center is offshore and $M_{\mathrm{I}}$ is 7.9 (E) see Fig. S7a, available as an electronic supplement to this paper). We note that the 24 June $1984 M_{\mathrm{s}} 6.732-\mathrm{km}$-deep thrust event occurred on the Los Muertos Trough (Byrne et al., 1985) near the offshore intensity center. With an intensity VII, the intensity center is onshore near Azua and $M_{\mathrm{I}}$ is 7.5 ((E) see Fig. S7b, available as an electronic supplement to this paper). There is an rms local minimum near the CHF intensity center (E) see Fig. S7a, available as an electronic supplement to this paper). If an intensity VII is adopted by CHF for Santo Domingo, then the intensity center lies within this local minimum, rather than offshore, and $M_{\mathrm{I}}$ is 7.5. Conversely, if an intensity VIII is adopted by WHB for Santo Domingo, then the intensity center lies offshore, and $M_{\mathrm{I}}$ is 8.0. That is, the solutions obtained using the CHF and WHB assignments are consistent, provided the same intensity is assigned at Santo Domingo. For the preferred intensity assignments, intensity at Santo Domingo is 7.5 and the intensity center is near Azua (Fig. 5). $M_{\mathrm{I}}$ is $7.4-7.5 \pm 0.2$. The offshore local rms minimum near the Los Muertos Trough remains, and $M_{\mathrm{I}}$ is $7.9-8.0 \pm 0.2$ for this alternate location.

There are several descriptions of the damage in Santo Domingo, presented here in chronological order:

1. " $\ldots$ on the 18 of the month of October of before mentioned year (1751) between 2 and 3 in the afternoon a horrific noise was heard, similar to a strong wind in a canyon but could not tell if it came from the air or from the ground and with it an earthquake equally as huge as terrible with continuous motion going from North to South although others claimed from East to West... a bit after 3 o'clock an attack in the space of 6 minutes, without pause, such a strong earthquake... from its impulsive subterranean roar felt and violent motion on all the churches and buildings, such that all of those of masonry in this city reached their total ruin... 8 tremors occurred later ." (Soler, 1980, quoting an Archivo General de Las Indias letter, dated October 19, 1751.)

2. "...but in the Spanish part, several convents and churches were thrown down in the city of St. Domingo..." (Anonymous, 1752).
3. "...to the north-east of town Saint-Michel was a hermitage that the earthquake of 1751 ruined..." (Moreau de Saint Mery, 1796).

4. "The city of Santo Domingo lost several buildings" (Mallet and Mallet, 1858).

5. "...lost its finest buildings, the convents of the monks of La Merci, the Franciscans and the Dominicans as well as the churches of St. Barbe, St. Lazare, St. Antoine, and St. Michel. The Cathedral remained intact because it was built entirely of compact hewn, limestone. Considerable damage to houses and main buildings of the city of Santo Domingo" (Scherer, 1912).

6. "At $3 \mathrm{PM}$ and at $5 \mathrm{PM}$... considerable damage in the homes and principal buildings in the city of Santo Domingo, there was a tsunami, the shaking continued up to the 25 (of October)..." (de Utrera [1927] quoting Scherer [1914]).

It is clear from these accounts that masonry buildings, probably of poor quality and construction, were ruined, but

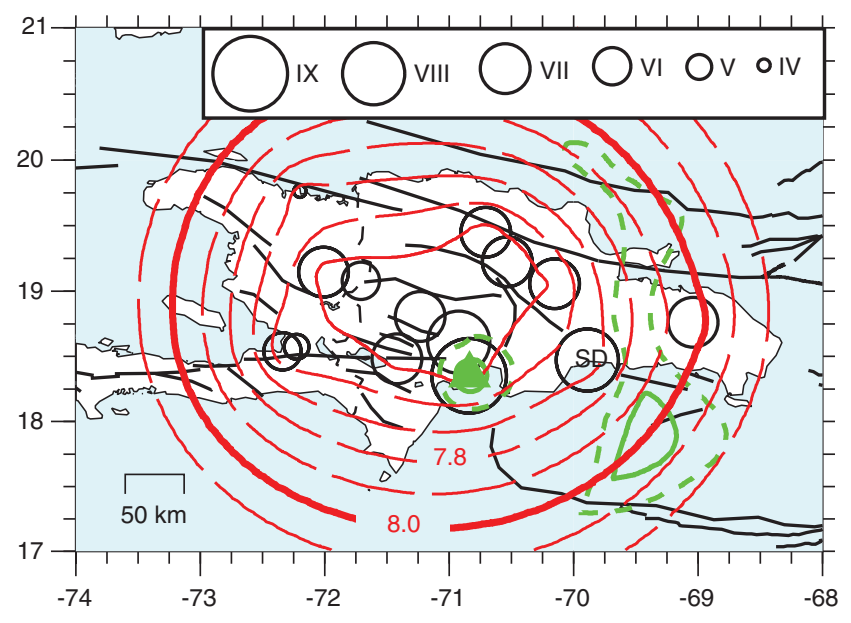

Figure 5. The 18 October 1751 earthquake with the preferred intensity assignments. The black circles are sites with MMI assignments with symbol size increasing with intensity. The black lines are active fault traces. The intensity center is a green filled triangle. Contours of $M_{\mathrm{I}}$ are dashed red lines. The rms $\left(M_{\mathrm{I}}\right)$ contour corresponding to the $67 \%$ and $95 \%$ confidence contours for location (Bakun and Wentworth, 1999) are shown as solid and dashed green lines, respectively. The SD marks the location Santo Domingo. 
that better buildings, such as the cathedral, were not destroyed. These accounts are consistent with the effects of the 2010 earthquake in Port-au-Prince, for which an MMI of 7.4 was assigned (Earthquake Hazards Program, 2010a). It is not surprising that intensity VII and VIII were assigned by WHB and CHF, respectively, for the 18 October 1751 effects at Santo Domingo. There is no mention of a tsunami in the contemporary accounts of Santo Domingo; a tsunami at Santo Domingo is first mentioned by Scherer (1914).

The 18 October 1751 earthquake has been interpreted as a thrust event in the Los Muertos thrust belt in the Caribbean Sea south of the Dominican Republic (Byrne et al., 1985; McCann et al., 2006; Ali et al., 2008; Calais et al., 2010) partly because of a tsunami, which presumably accompanied the earthquake. A tsunami suggests, but does not require, an offshore source location. Onshore earthquakes can, and do, trigger offshore slumps, landslides, and displacements of the ocean floor that generate tsunamis. The inference of a tsunami was based on the description by Scherer (1912) of the damage to Azua: "All its houses were thrown down and the sea overwhelmed the town." Hazard (1873) also wrote "The old town... was destroyed by an earthquake in 1751 . This terrible event led the sea up to the very town, when it was abandoned." The descriptions of Scherer and Hazard paraphrase the description of Moreau de Saint Mery (1796) about the damage to Azua; "But the earthquake of 1751 brought with it a fatal blow, destroying its houses and bringing the sea up to the point where the city was built." The ruins of old Azua and its church, however, are located in the town of Pueblo Viejo, $6 \mathrm{~km}$ from the shoreline at an elevation of $23 \mathrm{~m}$. Other historians (Tippenhauer, 1893; de Utrera, 1927; Soler, 1980), who examined primary letters in the Archivo General de Las Indias, do not mention flooding by the sea, and there are no contemporary reports of tsunami in Santo Domingo or elsewhere along the southern coast of the Dominican Republic. That is, there is no support in the original accounts for a tsunami associated with the 18 October 1751 event. There are, however, five Caribbean hurricanes listed for 1751 (Poey, 1855). Reports of flooding associated with a 1751 hurricane might have been mistakenly associated with the 18 October 1751 earthquake. For example, Moreau de Jonnes (1822), in his catalog of hurricanes, lists both a hurricane and an earthquake occurring in the month of October in 1751 in the Caribbean.

The 24 June $1984 M_{\mathrm{s}} 6.7$ event was felt in Puerto Rico, but there are no reports of the 18 October 1751 event there. One might expect that an M 8 event located near the 1984 epicenter would have caused strong shaking in Puerto Rico that would have been reported in 1751. On the other hand, an M 7.5 1751 onshore source near Azua is significantly smaller and farther from Puerto Rico, so it would cause significantly less damage there. The absence of a contemporary report of a tsunami and no felt reports in Puerto Rico are evidence, albeit not conclusive evidence, that the 18 October 1751 event was not an M 8 Los Muertos thrust belt earthquake.
Accounts (Tippenhauer, 1893; Soler, 1980) suggest frequent earthquakes between 28 October and 19 November 1751, felt between Santo Domingo and Port-au-Prince. These reports are consistent with 18 October 1751 aftershock activity near Azua and the onshore intensity center. Aftershocks are usually located near the mainshock rupture, providing additional support for an onshore location near Azua.

The 18 October 1751 event was followed 5 weeks later by the 21 November $1751 M_{\mathrm{I}} 6.5-6.7$ event on the Enriquillo fault system near Port-au-Prince (next section). A progression of events along a strike-slip fault can be explained by static Coulomb stress changes on adjacent sections of fault (e.g., the 1939-1992 east-to-west progression of large earthquakes along the North Anatolian fault [Stein et al., 2007]). While there is ample precedent for static stress triggering for adjacent sections of a strike-slip fault, static stress triggering of the Enriquillo fault sytem near Port-au-Prince by slip on the distant subduction-zone Los Muertos Trough is less plausible.

Our intensity assignments permit both offshore and onshore locations for the 18 October 1751 event. The weight of the evidence, however, favors an onshore location near the east end of the Enriquillo fault system:

1. An onshore intensity center better fits the preferred intensity assignments (Fig. 5),

2. There are no contemporary reports of an October 1751 tsunami, which would have been expected for an M 7.9-8.0 offshore source,

3. The event was not reported felt in Puerto Rico, even though an M 8 offshore source would have caused damage there,

4. The frequent earthquakes felt between Santo Domingo and Port-au-Prince, 28 October-19 November, are consistent with 18 October aftershock activity near the onshore source, and

5. Static stress triggering of the 21 November 1751 event is more plausible for an onshore source.

For these reasons, we associate the 18 October 1751 event with the Enriquillo fault system, including the mapped and blind thrust faults near Azua (Fig. 5). $M_{\mathrm{I}}$ is 7.4-7.5 \pm 0.2 .

\section{November 1751}

Port-au-Prince and the plain of Cul-de-Sac were severely damaged. The intensity centers for the CHF and WHB and preferred intensity assignment sets are near Port-au-Prince, $25 \mathrm{~km}$ east of the 2010 mainshock epicenter (Fig. 6; (E) see Fig. S8, available as an electronic supplement to this paper). $M_{\mathrm{I}}$ is $6.6 \pm 0.2$. An $M_{\mathrm{I}} 5.7$ aftershock followed on 22 November, causing additional damage in Port-au-Prince. Numerous earthquakes were felt in Haiti over the next 20 days.

\section{June 1770}

Felt across the entire island of Hispaniola and in Jamaica, the 1770 earthquake destroyed Port-au-Prince: “...not 
one house was left standing and more than 500 were buried in the ruins..." (Southey, 1827). The plains of Leogane, Portau-Prince, and Petit Goave suffered considerably. Farther west, Les Cayes suffered serious damage and part of the shoreline sank (Moreau de Saint Mery, 1796). The earthquake was preceded by 10 reported earthquakes in Haiti between 1765 and 1770, mostly felt in Port-au-Prince, and was followed by many aftershocks, described as "almost without interruption" for the next 2 days (Perrey, 1847) and daily shocks for the next month (Moreau de Jonnes, 1822). Counts of felt aftershocks were reported for months afterward.

The intensity center obtained using the WHB intensity assignments is $17 \mathrm{~km}$ south of that obtained using the CHF assignments ((E) see Fig. S9, available as an electronic supplement to this paper). The intensity center for the preferred intensity assignment set is near the Enriquillo fault, $34 \mathrm{~km}$ west of the 2010 mainshock epicenter (Fig. 7). $M_{\mathrm{I}}$ is $7.5 \pm 0.2$. The rupture length of an $\mathbf{M} 7.5$ earthquake is about $200 \mathrm{~km}$ (Wells and Coppersmith, 1994) so that the 1770 rupture may have overlapped the nearby shorter 9 November 1701 and the 12 January 2010 earthquake rupture zones.

\section{April 1860}

The only significant earthquake between 1770 and 2010 possibly on the Enriquillo fault system occurred on 8 April 1860, accompanied by a tsunami in Anse-a-Veau (Taber, 1922). The intensity center is located on the coast north of the Enriquillo fault (Fig. 8; (E) see Fig. S10, available as an electronic supplement to this paper). $M_{\mathrm{I}}$ is

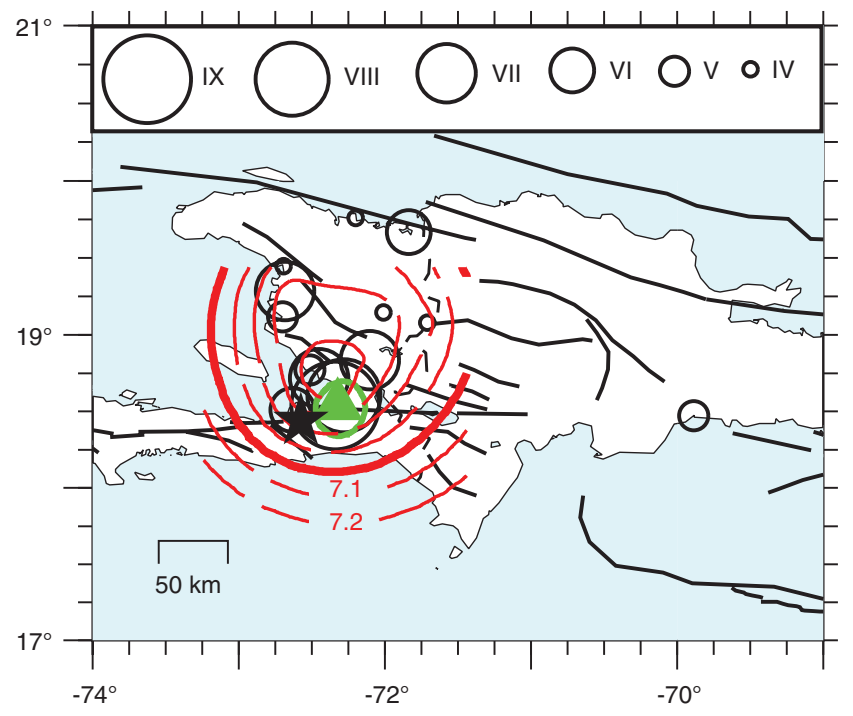

Figure 6. The 21 November 1751 earthquake with the preferred intensity assignments. The black circles are sites with MMI assignments with symbol size increasing with intensity. The black lines are active fault traces. The intensity center is a green filled triangle. Contours of $M_{\mathrm{I}}$ are dashed red lines. The rms $\left(M_{\mathrm{I}}\right)$ contour corresponding to the $67 \%$ confidence contours for location (Bakun and Wentworth, 1999) is a green line. The epicenter of the 12 January 2010 mainshock is shown as a black star.

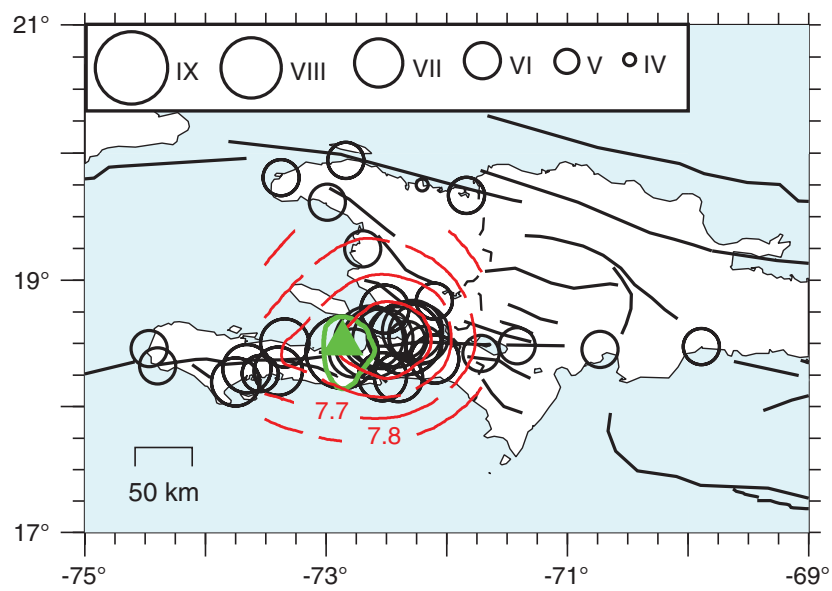

Figure 7. The 3 June 1770 earthquake with the preferred intensity assignments. The black circles are sites with MMI assignments with symbol size increasing with intensity. The black lines are active fault traces. The intensity center is a green filled triangle. Contours of $M_{\mathrm{I}}$ are dashed red lines. The rms $\left(M_{\mathrm{I}}\right)$ contour corresponding to the $67 \%$ confidence contours for location (Bakun and Wentworth, 1999) is a green line.

$6.3 \pm 0.2$. Even if located on the Enriquillo fault system, the moment release in 1860 was insignificant compared with that of the larger eighteenth century events.

\section{Discussion}

Significant earthquakes with intense aftershock activity occurred along the Enriquillo fault system from 1701 to 1770. No comparable earthquakes occurred after 1770, until the 12 January 2010 earthquake. That is, the 70 years of

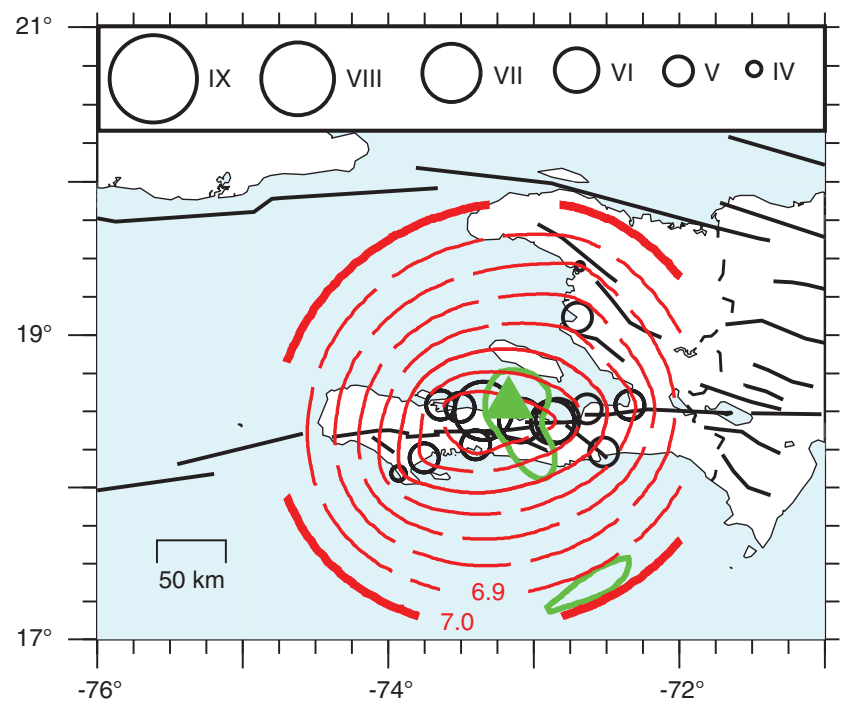

Figure 8. The 8 April 1860 earthquake with the preferred intensity assignments. The black circles are sites with MMI assignments with symbol size increasing with intensity. The black lines are active fault traces. The intensity center is a green filled triangle. Contours of $M_{\mathrm{I}}$ are dashed red lines. The rms $\left(M_{\mathrm{I}}\right)$ contour corresponding to the $67 \%$ confidence contours for location (Bakun and Wentworth, 1999) is a green line. 
intense seismic activity of the eighteenth century, culminating in the $1770 M_{\mathrm{I}} 7.5$ earthquake, was followed by 240 years of relative seismic quiescence. Smaller earthquakes in the region, however, were reported in the eighteenth, nineteenth, and twentieth centuries (Fig. 9; (E) see Table S1, available in the electronic supplement to this paper). A comparable pattern of seismic activity in the San Francisco Bay region has been characterized as a hundreds-of-years-long seismic cycle (e.g., Ellsworth et al., 1981): each cycle consists of a period of significant earthquake activity in a region culminating in a large event, followed by a period of relative quiescence. The decades before the 1906 earthquake on the San Andreas fault in northern California were seismically active compared with the relative quiescence of the region since 1906, and small felt earthquakes in the San Francisco Bay region have been reported regularly since 1850 (Bakun, 1999). That is, the pattern of seismic activity along the Enriquillo fault system is consistent with the seismic cycle model of tectonic activity of Ellsworth et al. (1981).

There are no reports of earthquakes, large or small, from southwest Hispaniola before 1700. There is no reason to suppose that small earthquakes did not occur before 1700 . Rather, the decreasing trend in the count of felt independent (non aftershock) small earthquakes with elapsed time back to about 1700 (Fig. 9) suggests that the detection threshold has increased with time, as might be expected. Before 1700, the detection threshold apparently is greater than about magnitude 6 . The felt reports of the $1562 M_{\mathrm{I}} 7.5$ earthquake in northern Hispaniola (ten Brink et al., 2012) are sufficient to estimate a location and magnitude. Comparable reports of the $1770 M_{\mathrm{I}} 7.5$ earthquake on the Enriquillo fault system would have been available if the 1770 event had occurred in 1562. That is, the detection threshold for the Enriquillo fault system in the sixteenth and seventeenth centuries is between M 6 and M 7.5. Towns existed in southwest Hispaniola during these centuries, and it was in their financial interests to report earthquake damage to the Spanish king and ask for repair funds. There were regular reports to the king during the sixteenth and seventeenth centuries, but no reports of damage that might be ascribed to earthquakes in southwest

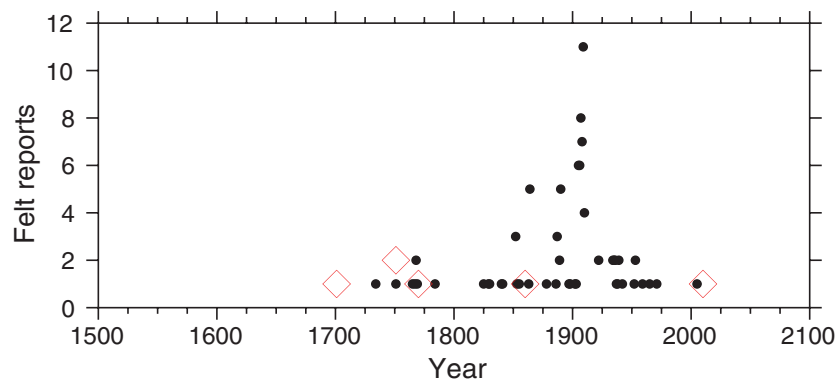

Figure 9. Seismic activity on the Enriquillo fault system. The significant earthquakes (Table 1) are shown as red diamonds. The count of felt reports by calendar year for possible independent small $(\mathrm{M}<6)$ earthquakes (E) see Table S1, available as an electronic supplement to this paper) are black dots. The numerous felt aftershocks associated with the significant earthquakes are not represented.
Hispaniola. Although it is impossible to prove that a damaging sixteenth or seventeenth century Enriquillo fault system earthquake did not occur, the lack of reports suggests that the Enriquillo fault system during the sixteenth and seventeenth centuries was relatively aseismic, like in the nineteenth and twentieth centuries.

The 1701 and 2010 earthquakes appear to be located on the Leogane-Petit Goave section of associated strike-slip and thrust faults that comprise the Enriquillo fault system. First, the 1701 intensity center is located near the 2010 rupture. Second, the road leading from Leogane to Petit Goave along the coast collapsed during the 1701 event (Moreau de Saint Mery, 1798), while part of the coast there collapsed in 2010 due to lateral extension (Hayes et al., 2010). These reports suggest that shaking in 1701 and 2010 was strong enough to cause ground failure in the weak soils along the Leogane-toPetit Goave coast. The source of this shaking was necessarily nearby, presumably on the same section of the Enriquillo fault system. Port-au-Prince did not exist in 1701, so damage reports there cannot be compared.

The sequence of large earthquakes in 1751 and 1770 may have ruptured the entire Enriquillo fault system from east to west, starting at the eastern end in the Dominican Republic and extending to at least Anse-a-Veau, $235 \mathrm{~km}$ to the west, and perhaps farther west to the vicinity of Les Cayes, a total of $285 \mathrm{~km}$. If so, the decades-long east-to-west progression of activity would be similar to the 1939-1992 east-to-west progression of large earthquakes along the North Anatolian fault (Stein et al., 2007).

The 1770 earthquake source region is west of Port-auPrince and the rupture length of the 21 November 1751 $M_{\mathrm{I}} 6.6$ event, located near Port-au-Prince, was probably not greater than a few tens of kilometers. The topographic expression of the Enriquillo fault, however, extends about 150 kilometers farther east. Our preferred location for the 18 October 1751 event is onshore near the farthest east end of the Enriquillo fault system, presumably with westward rupture on the Enriquillo fault system toward Portau-Prince. If, however, the 18 October 1751 event is located offshore, there is no evidence that the $150 \mathrm{~km}$ of the Enriquillo fault system east of Port-au-Prince has been seismically active in the past 500 years.

The average rate of $7 \pm 2 \mathrm{~mm} /$ year of accumulated leftlateral slip on the Enriquillo fault system estimated by Manaker et al. (2008) was for a kinematic block model for the northern Caribbean in which the Enriquillo fault system was modeled as a single vertical fault. The 2010 earthquake, however, caused uplift north of the fault and subsidence south of the fault (Hayes et al., 2010; Calais et al, 2010), and aftershocks appear to be concentrated on a north-dipping plane. The coseismic change in topography from a northdipping thrust fault is opposite to the topography across the fault and at least three rupture planes-a north-dipping blind thrust, a south-dipping blind thrust, and deep leftlateral strike-slip fault—are necessary to model the 2010 source (Hayes et al., 2010). The post-2010 earthquake 
analysis by Calais et al. (2010) of GPS and InSAR data modeled the Enriquillo fault system as a single north-dipping fault because the spatial density of the GPS network was not sufficient to model the multifault Enriquillo fault system complexities revealed by the 2010 earthquake. They found $5 \mathrm{~mm} /$ year of accumulated left-lateral slip and $2 \mathrm{~mm} /$ year of accumulated reverse slip.

Prentice et al. (2010) found only a set of 1.3-3.3-m offsets on the Enriquillo fault that could be associated with the eighteenth century earthquakes. They inferred from the size of the offsets that only one M 7 event could have been involved, but the moment magnitude was probably smaller than 7.6. The eighteenth century earthquakes, like the 2010 event, apparently resulted in significantly less slip on the Enriquillo fault than would be expected from their magnitudes. By default, significant slip during the eighteenth century earthquakes must have involved nearby blind thrust faults. We do not know the source mechanisms for any of the eighteenth century events. Specifically, we do not know which nearby blind thrust faults, south-dipping or northdipping, were involved, or when. Perhaps uplift south of the fault in one eighteenth century event was overwritten by uplift north of the fault in the next.

If we consider the 2010 earthquake to be a rerupture of the 1701 earthquake source zone, then the recurrence interval on the Enriquillo fault system is 310 years. Using a slip accumulation rate of $7 \mathrm{~mm} / \mathrm{yr}$ (Manaker et al., 2008; Calais et al., 2010), the accumulated average slip would be about $2.2 \mathrm{~m}$ over 310 years. The total moment release for the eighteenth century earthquakes, $3.9 \times 10^{27} \mathrm{dyn} \cdot \mathrm{cm}$, is almost all contributed by the 18 October $1751 M_{\mathrm{I}} 7.4-7.5$ and 3 June $1770 M_{\mathrm{I}} 7.5$ events. Using a shear modulus of $3 \times 10^{11} \mathrm{dyn} / \mathrm{cm}^{2}$, a depth of $15 \mathrm{~km}$ and fault lengths of $285 \mathrm{~km}$ and $235 \mathrm{~km}$, the average slip (Brune, 1968) in these earthquakes would have been 3.0 and $3.7 \mathrm{~m}$, respectively. Using a depth of $20 \mathrm{~km}$ (Altidor et al., 2010), the average slip would be $2.3 \mathrm{~m}$ and $2.8 \mathrm{~m}$, respectively. Given the likely unknown eighteenth century source complexities described previously, it should come as no surprise that the slip inferred from the summed moments is greater than the $2.2 \mathrm{~m}$ of accumulated slip inferred from the slip rates of Manaker et al. (2008) and Calais et al. (2010).

Earthquakes are complicated phenomena that do not conform to simple models of fault stress regeneration and earthquake recurrence. Earthquakes can, and do, occur before, and after, the accumulated slip restores the slip in the preceeding events (Mulargia and Gasparini, 1995; Murray and Segall, 2002). That is, a twenty-first century series of damaging earthquakes on the Enriquillo fault system is plausible, regardless of any accumulated and inferred slip mismatch. The eighteenth century sequence of devastating earthquakes demonstrates that the Enriquillo fault system is seismically active. That it has been largely quiescent over the past 240 years is no comfort because considerable potential slip has accumulated since the eighteenth century events (Calais et al., 2010). Moreover, the 2010 earthquake is evidence that the regional ambient stress level along the Enriquillo fault system is now sufficient to generate large earthquakes.

The 12 January 2010 M 7.0 earthquake was not a large event but caused considerable devastation and fatalities in Port-au-Prince, largely because of inadequate building practices. Seismic hazard mitigation efforts in Haiti and the Dominican Republic should be strengthened to lessen the devastating effects of future earthquakes. The devastating earthquakes that occurred along the Enriquillo fault system in the eighteenth century and throughout southern Haiti and the Dominican Republic since 1500 suggest that the seismic hazard mitigation efforts should address the effects of strong earthquakes not only on the Enriquillo fault system, but throughout southern Haiti and the southern Dominican Republic.

\section{Conclusions}

1. A series of devastating earthquakes on the Enriquillo fault system in the eighteenth century started with an $M_{\mathrm{I}} 6.6$ earthquake on 9 November 1701 near the location of the 12 January 2010 Haiti earthquake. Accounts of the shaking in the 1701 earthquake are similar to those of the 2010 earthquake.

2. The accounts for the 18 October 1751 event can be satisfied by two source solutions: (a) our preferred solution, an $M_{\mathrm{I}}$ 7.4-7.5 earthquake on or near the east end of the Enriquillo fault system; and (b) an $\mathrm{M}_{\mathrm{I}}$ 7.9-8.0 event on the Los Muertos thrust belt.

3. A series of large earthquakes migrating from east to west possibly started with the 18 October $1751 M_{\mathrm{I}} 7.4-7.5$ earthquake near the eastern end of the fault in the Dominican Republic, followed by the 21 November $1751 M_{\mathrm{I}} 6.6$ earthquake near Port-au-Prince, Haiti, and the 3 June 1770 $M_{\mathrm{I}} 7.5$ earthquake west of the 2010 earthquake rupture.

4. Other than the eighteenth century earthquakes and the 2010 earthquake, we associate no other post-1500 significant earthquakes with the Enriquillo fault system, but the uncertain sixteenth and seventeenth century detection threshold is probably greater than M 6.25.

5. The 2010 Haiti earthquake may mark the beginning of a new cycle of large earthquakes on the Enriquillo fault system after 240 years of seismic quiescence.

6. The entire Enriquillo fault system appears to be seismically active. Haiti and the Dominican Republic should prepare for future devastating earthquakes on the Enriquillo fault system.

\section{Data and Resources}

Historical earthquake accounts and intensity assignments are taken from Flores et al. (2011). MMI intensity assignments for recent earthquakes were obtained from the USGS Earthquake Hazards Program (http://earthquake.usgs.gov/ earthquakes/dyfi/, last accessed May 2011). Damage reports 
in 2010 in Port-au-Prince were obtained from the USGS/ EERI Advance Reconnaissance Team report (http://www .eqclearinghouse.org/20100112-haiti/wp-content/uploads/ 2010/02/USGS_EERI_HAITI_V1.1.pdf, last accessed May 2011). Contemporary sixteenth, seventeenth, and eighteenth century maps of Hispaniola were obtained from the Norman B. Leventhal Map Center, Boston Public Library (http://maps.bpl.org, last accessed March 2011). The intensity attenuation model was calculated using the Microsoft EXCEL data analysis regression tool (Middleton, 1995). The list of small earthquakes (E) see Table S1, available in the electronic supplement to this paper) was compiled using the Bulletins de l'Observatoire Meteorologique du Seminaire College St. Martial Port-au-Prince, the USGS Earthquake Hazards Program (http://earthquake.usgs.gov/earthquakes/eqarchives /epic/, last accessed March 2011), and the International Seismological Center (2001). A surface-wave magnitude of the 4 August 1946 Puerto Rico Trench earthquake was obtained from the USGS Earthquake Hazards Program (http://earthquake.usgs.gov/earthquakes/eqarchives/epic/, last accessed March 2011). The figures were made using the Generic Mapping Tools software package by Wessel and Smith (1991).

\section{Acknowledgments}

Bill Ellsworth and Ross Stein encouraged this collaborative effort and provided valuable comments and support throughout. We thank Tony Crone and Rich Briggs for their help in understanding the effects of the 2010 event and Colleen Hurter from Marine Biological Laboratory and Woods Hole Oceanographic Institution Library for her help in finding historical references. Bill Ellsworth and Bill Stuart provided helpful critical comments on the manuscript. We thank Jim Dewey and several anonymous reviewers for their thoughtful and thorough reviews.

\section{References}

Abe, K. (1981). Magnitudes of large shallow earthquakes from 1904 to 1980, Phys. Earth Planet. In. 27, 72-92, doi 10.1016/0031-9201 (81)90088-1.

Ali, S. T., A. M. Freed, E. Calais, D. M. Manaker, and W. R. McCann (2008). Coulomb stress evolution in Northeastern Caribbean over the past 250 years due to coseismic, postseismic and interseismic deformation, Geophys. J. Int. 174, 904-918, doi 10.1111/j.1365246X.2008.03634.X.

Altidor, J.-R., A. Dieuseul, J. G. Armbruster, H. Benz, C. Dietel, W. L. Ellsworth, D. Given, S. E. Hough, D. Ketchum, J. H. Luegert, J. Z. Maharrey, M. E. Meremonte, D. E. McNamara, B. S. Mildor, W. D. Mooney, and R. Sell (2010). Structure of the aftershock zone of the $M_{\mathrm{w}} 7.0$ Haiti earthquake from the USGS-BME portable instrument deployment, EOS Amer. Geophys. Un. (abstract).

Anonymous (1752). Account of the Late Earthquake in the island of Hispaniola, or St. Domingo, from the French relation, The Gentleman's Magazine 22, E. Cave (printer), London, 91.

Bakun, W. H. (1999). Seismic activity in the San Francisco Bay region, Bull. Seismol. Soc. Am. 89, 764-784.

Bakun, W. H. (2006). Estimating locations and magnitudes of earthquakes in southern California from modified Mercalli intensities, Bull. Seismol. Soc. Am. 96, 1278-1295, doi 10.1785/0120050205.

Bakun, W. H., and C. M. Wentworth (1997). Estimating earthquake location and magnitude from seismic intensity data, Bull. Seismol. Soc. Am. 87, $1502-1521$.
Bakun, W. H., and C. M. Wentworth (1999). Erratum to Estimating earthquake location and magnitude from seismic intensity data, Bull. Seismol. Soc. Am. 89, 557.

Bakun, W. H., and M. G. Hopper (2004). Magnitudes and locations of the 1811-1812 New Madrid, Missouri, and the 1886 Charleston, South Carolina, earthquakes, Bull. Seismol. Soc. Am. 94, 64-75, doi $10.1785 / 0120020122$.

Bettembourg, J. B., V. Schneider, and E. Schumacker (comp.) (1955). Le Tremblement de Terre D'Anse-a-Veau, Bulletin Annuel de l'Observatoire Meterologique du Petit-Seminarie College St-Martial, Port-auPrince, Haiti, Annee, 59-81.

Brune, J. N. (1968). Seismic moment, seismicity, and rate of slip along major fault zones, J. Geophys. Res. 73, 777-784, doi 10.1029/ JB073i002p00777.

Byrne, D. B., G. Suarez, and W. R. McCann (1985). Muertos Trough subduction-microplate tectonics in the northern Caribbean? Nature 317, 420-421, doi 10.1038/317420a0.

Calais, E., A. Freed, G. Mattioli, F. Amelung, S. Jonssson, P. Jansma, S.-H. Hong, T. Dixon, C. Prepetit, and R. Momplaisir (2010). The January $12,2010, M_{\mathrm{w}} 7.0$ earthquake in Haiti: Context and mechanism from an integrated geodetic study, Nat. Geosci. 3, 794-799.

Charlevoix, P. F. X. (1730). Histoire de L'Isle Espagnole ou de S. Domingue 1, J. Guerin, Paris, 541 p.

de Utrera, C. (1927). Santo Domingo, dilucidaciones históricas (I-II), 1995 edition, $1190 \mathrm{p}$ (in Spanish).

de Velasco, J. L. (1894). Geografia y descripcîon de Las Indias, originally published 1571-1574, Justo Zaragoza (Editor), Real Academia de la Historia Madrid, 808 p.

Dolan, J. F., and D. J. Wald (1998). The 1943-1953 north-central Caribbean earthquakes: Active tectonic setting, seismic hazard, and implications for Caribbean-North America plate motion, Geol. Soc. Am. Spec. Pap. 326, 143-169.

Dolan, J. F., H. T. Mullins, and D. J. Wald (1998). Active tectonics of the northcentral Caribbean: Oblique collision, strain partitioning, and opposing subducted slabs, Geol. Soc. Am. Spec. Pap. 326, $1-61$.

Earthquake Hazards Program (2010a). Did You Feel It?, U.S. Geol. Surv., http://earthquake.usgs.gov/earthquakes/dyfi/, (last accessed May 2011).

Earthquake Hazards Program (2010b). Global earthquake search, U.S. Geol. Surv., http://earthquake.usgs.gov/earthquakes/eqarchives/epic/, (last accessed March 2011).

Eberhard, M. O., S. Baldridge, J. Marshall, W. Mooney, and G. J. Rix (2010). The $M_{\mathrm{w}} 7.0$ Haiti earthquake of January 12, 2010: USGS/ EERI advance reconnaissance team report v.1.1, http://www .eqclearinghouse.org/20100112-haiti/wp-content/uploads/2010/ 02/USGS_EERI_HAITI_V1.1.pdf (last accessed May 2011).

Ellsworth, W. L., A. G. Lindh, W. H. Prescott, and D. G. Herd (1981). The 1906 San Francisco earthquake and the seismic cycle, in Earthquake Prediction: An International Review, Monograph, Maurice Ewing Series 4, D. W. Simpson and P. G. Richards (Editors), American Geophysical Union, Washington, D.C., 126-140.

Flores, C. H., U. S. ten Brink, and W. H. Bakun (2011). Accounts of damage from historical earthquakes in the north-eastern Caribbean, to aid in the detrmination of their location and intensity magnitudes, US Geol. Surv. Open-File Rep. 2011-1133, 219 pp (in press).

Garcia, J. G. (1900). Compendio de la historia de Santo Domingo Third Ed., Vol. 1-3, Garcia Brothers, Santo Domingo.

Hayes, G. P., R. W. Briggs, A. Sladen, E. J. Fielding, C. Prentice, K. Hudnut, P. Mann, F. W. Taylor, A. J. Crone, R. Gold, T. Ito, and M. Simons (2010). Complex rupture during the 12 January 2010 Haiti earthquake, Nat. Geosci. 3, 800-805, doi 10.1038/ngeo977.

Hazard, S. (1873). Santo Domingo, past and present, with a glance at Hayti Harper \& Brothers, New York, 511 p.

Heubeck, C., and P. Mann (1991). Structural geology and Cenozoic tectonic history of the Southeastern Termination of the Cordillera Central, Dominican Republic, Geol. Soc. Am. Spec. Pap. 262, 315-336. 
Kelleher, J., L. Sykes, and J. Oliver (1973). Possible criteria for predicting earthquake locations and their application for major plate boundaries of the Pacific and the Caribbean, J. Geophys. Res. 78, 2547-2585, doi 10.1029/JB078i014p02547.

Lynch, J. J., and R. R. Bodle (1948). The Dominican earthquakes of August 1946, Bull. Seismol. Soc. Am. 38, 1-17.

Mallet, R., and J. W. Mallet (1858). Earthquake catalogue of the British Association: With the discussion, curves and maps, etc., Transactions of the British Association for the Advancement of Science, 1852 to 1858, Taylor and Francis London, $674 \mathrm{p}$.

Manaker, D. M., E. Calais, A. M. Freed, T. Ali, P. Przybylski, G. Mattioli, P. Jansma, C. Prepetit, and J. B. De Chabalier (2008). Interseismic plate coupling and strain partitioning in the northeastern Caribbean, Geophy. J. Intern. 174, 889-903, doi 10.1111/j.1365-246X.2008.03819.x.

Mann, P., G. Draper, and J. F. Lewis (1991). An overview of the geologic and tectonic development of Hispaniola, Geol. Soc. Am. Spec. Publ. 262, $1-28$.

Mann, P., F. Taylor, R. Edwards, and T. Ku (1995). Actively evolving microplate formation by oblique collision and sideways motion along strike-slip faults: An example from the northeastern Caribbean plate margin, Tectonophysics 246, 1-69, doi 10.1016/0040-1951(94) 00268-E.

McCann, W. R. (2006). Estimating the threat of tsunamogenic earthquakes and earthquake induced-landslide tsunami in the Caribbean, in Caribbean Tsunami Hazard, A. Mercado and P. Liu (Editors), World Scientific Publishing, Singapore 43-65.

McLaughlin, P. P., and B. K. Sen Gupta (1991). Migration of Neogene marine environments, southwestern Dominican Republic, Geology 19, 222-225.

Middleton, M. R. (1995). Data anlysis using Microsoft EXCEL 5.0, Duxbury Press, Wadsworth Publishing Company, Belmont, California, $270 \mathrm{pp}$.

Moreau de Jonnes, A. (1822). Histoire Physique des Antilles Francaises, Migneret, Paris, $560 \mathrm{p}$.

Moreau de Saint Mery, L. E. (1796). Description Topographique et politique de la partie espangnole de l'isle Saint-Domingue 1, Moreau de Saint Mery, Philadelphia, 307 p.

Moreau de Saint Mery, L. E. (1798). Description Topographique, Physique, Civile, Politique et Historique de la Parte Francaise de L'isle Saint-Dominique 2, Moreau de Saint Mery, Philadelphia, 856 p.

Mulargia, F., and P. Gasperini (1995). Evaluation of the applicability of the time- and slip-predictable earthquake recurrence models to Italian seismicity, Geophys. J. Int. 120, 453-473, doi 10.1111/j.1365246X.1995.tb01832.x.

Murray, J., and P. Segall (2002). Testing time-predictable earthquake recurrence by direct measurement of strain accumulation and release, Nature 419, 287-291, doi 10.1038/nature00984.

O' Loughlin, K. F., and J. F. Lander (2003), Caribbean Tsuamis: A 500-Year History from 1498-1998, Kluwer Academic Publishers, Dordrecht, Netherlands, $263 \mathrm{p}$.

Oldmixon, J. (1741). The British Empire in America, Vol 2, Second Ed., J. Brotherton, J. Clarke, London, 478 p.

Pacheco, J., and L. R. Sykes (1992). Seismic moment catalog of large, shallow earthquakes 1900 to 1989, Bull. Seismol. Soc. Am. 82, 1306-1349.

Perrey, A. (1847). Sur Les Tremblements de Terre Aux Antilles, Memoires de l'Academie des sciences, arts et belle-lettres de Dijon 1845-1846 325-479.

Pindell, J. L., and S. F. Barrett (1990). Geological evolution of the Caribbean region; a plate tectonic perspective, in The Geology of North America, The Caribbean Region G. Dengo and J. E. Case (Editors), Geol. Soc. Am., Vol. H, 405-432.

Poey, A. (1855). A Chronological Table, Comprising 400 Cyclonic Hurricanes Which Have Occurred in the West Indies and in the North Atlantic within 362 Years from 1493 to 1855, with NA bibliographical list of accounts of hurricanes, J. Roy. Geogr. Soc. Lond. 25, 291-328.
Poey, A. (1857). Catalogue Chronologique des tremblements de terre ressentis dans les Indies-Occidentales, 1530-1857, Аnпиаire de la Societe Meteorologique de France 5, 75-127.

Prentice, C. S., P. Mann, A. J. Crone, R. D. Gold, K. W. Hudnut, R. W. Briggs, R. D. Koehler, and P. Jean (2010). Seismic hazard of the Enriquillo-Plantain Garden fault in Haiti inferred from paleoseismology, Nat. Geosc. 3, 789-793, doi 10.1038/ngeo991.

Pubellier, M., A. Mauffret, S. Leroy, J. M. Vlia, and H. Amilcar (2000). Plate boundary readjustment in oblique convergence: Example of the Neogene of Hispaniola, Greater Antilles, Tectonics 19, 630-648, doi 10.1029/2000TC900007.

Richter, C. F. (1958). Elementary Seismology W. H. Freeman and Co., San Francisco, California, 758 pp.

Russo, R. M., and A. Villaseñor (1995). The 1946 Hispaniola earthquake and the tectonics of the North America-Caribbean plate boundary zone, northeastern Hispaniola, J. Geophys. Res. 100, 6265-6280, doi 10.1029/94JB02599.

Scherer, J. (1912). Great earthquakes in the Island of Haiti, Bull. Seismol. Soc. Am. 2, 161-180.

Scherer, J. (1914). Catalogue Chronologique des Tremblements de Terre Ressentis Dans l'Ile d'Haiti de 1551 a 1900, Bulletin Semestriel de L'Observatoire Meteorologique du Seminaire-College St-Martial, Port-au-Prince, Haiti Juillet-Decembre 1913, 147-151.

Soler, R. S. (1980). Santo Domingo Tierra de Frontera (1750-1800), Publicaciones de la Escuela de estudios hispano-americanos de Sevilla, Seville, Spain, 534 p (in Spanish).

Southey, T. (1827). Chronological History of the West Indies, Vol. 2, Longman, Rees, Orme, Brown \& Green, London, 552 p.

Stein, R. S., A. A. Barka, and J. H. Dieterich (2007). Progressive failure on the North Anatolian fault since 1939 by earthquake stress triggering, Geophs. J. Int., 128, 589-604, doi 10.1111/j.1365246X.1997.tb05321.x.

Sykes, L. R., and M. Ewing (1965). The seismicity of the Caribbean region, J. Geophys. Res. 70, 5065-5074.

Taber, S. (1922). The seismic belt in the Greater Antilles, Bull. Seismol. Soc. Am. 7, 199-219.

ten Brink, U., W. H. Bakun, and S. H. Flores (2011). Historical perspective on seismic hazard to Hispaniola and the NE Caribbean, J. Geophys. Res. 116, doi 10.1029/2011JB008497.

Tippenhauer, L. (1893). Liste der Erdebebe, auf Haiti in Die Insle Haiti, Leipzip 170-175 (in German).

Wells, D. L., and K. J. Coppersmith (1994). New empirical relationships among magnitude, rupture length rupture width, rupture area, and surface displacement, Bull. Seismol. Soc. Am. 84, 974-1002.

Wessel, P., and W. H. F. Smith (1991). Free software helps map and display data, Eos Trans. AGU 72, 441, doi 10.1029/90EO00319.

Wood, H. O., and F. Neumann (1931). Modified Mercalli intensity scale of 1931, Bull. Seismol. Soc. Am. 21, 277-283.

Working Group on California Earthquake Probabilities (WGCEP) (2003). Earthquake probabilities in the San Francisco Bay Region: 20022031, U. S. Geol. Surv. Tech. Rept. OFR 03-214.

U.S. Geological Survey

345 Middlefield Rd.

Menlo Park CA 94025

(W.H.B.)

U.S. Geological Survey

384 Woods Hole Rd.

Woods Hole MA 02543

(C.H.F., U.S.t.B.)

Manuscript received 11 March 2011 